\title{
APPRAISAL OF COMBINED AGREEMENTS IN BOT PROJECT FINANCE: FOCUSED ON MINIMUM REVENUE GUARANTEE AND REVENUE CAP AGREEMENTS
}

\author{
Jaebum JUN \\ Inha University, College of Engineering, Department of Architectural Engineering, \\ 253 Yonghyun-dong, Nam-gu, Incheon, 402-751, Korea \\ E-mail: junjb@inha.ac.kr
}

Received 20 August 2009; accepted 2 February 2010

\begin{abstract}
Limited public funds for infrastructures have the government consider joining the private in a BOT project finance scheme. Generally, the BOT projects entail lots of managerial flexibilities that may induce the radical change of project's cash flows, an asymmetric payoff, when facing on the uncertainties due to the BOT project finance's unique characteristics. Among various managerial flexibilities in the BOT projects, the MRG (Minimum Revenue Guarantee) and the RCP (Revenue Cap) agreements are frequently used to protect the government and the developer from the operational risk. However, the combined effect of the MRG and RCP on the project value is not understood well because the traditional capital budgeting theory, the NPV (Net Present Value) analysis, is limited to assess the contingency of these agreements. So, the purpose of this paper is to develop the numerical model to assess the combined impact of the MRG and RCP agreements on the project value based on the option pricing theory and to suggest a theoretical framework. The approach applied in this paper is justified with the hypothetical BOT toll case and some meaningful conclusions are drawn from. The results by the option pricing concept are analyzed over those by NPV analysis and, finally, the combined value of the MRG and RCP agreements appears significant relative to the project value.
\end{abstract}

KEYWORDS: BOT (Build-Operate-Transfer) project finance; Option pricing theory; MRG (Minimum Revenue Guarantee) agreement; RCP (Revenue Cap) agreement; Repeatedly-exercisable call-put compound option

\section{INTRODUCTION}

Limitation of public funds for infrastructures has had the government consider joining the private developer in a BOT (BuildOperate-Transfer) project finance scheme. The BOT scheme followed by the stakeholders is regarded effective because it is based on the notion that the specific stakeholder will best treat with the specific risks involved in a project. The risk evolution that occurs in a BOT project is too complex for the project stakeholders to predict. Therefore, the government and the developer have become closer to hedge the risks through comprehensive cooperation. The BOT project finance in various project finance schemes has worked well in a way to transfer the ownership from the private to the public upon the concession. The BOT project finance entails lots of unique characteristics such as huge project size, long concession

International Journal of Strategic Property Management

ISSN 1648-715X print / ISSN 1648-9179 online (C) 2010 Vilnius Gediminas Technical University

http://www.ijspm.vgtu.lt

DOI: $10.3846 /$ ijspm.2010.11 
period, or contractual complexity which can fall into two folds; "uncertainty" and "managerial flexibility". Simply speaking, the "uncertainty" stands for the uncertain change of the revenue (or cash flow) the project generates unlike what expected and the "managerial flexibility" represents an event or reaction necessary to be exercised when the management's decision changes or predetermined agreements meet specific conditions due to unpredictable uncertainty during the project. The combined effect of both of "uncertainty" and "managerial flexibility" may generate an asymmetric payoff condition called "contingent claim" where the project's revenue drastically shift and the fact one of the most popular capital budgeting theories, the NPV (Net Present Value) analysis, is limited to assess the value change caused by these asymmetric payoffs makes people seek alternations to resolve this issue. Among various asymmetric payoffs take place in a BOT project, the MRG (Minimum Revenue Guarantee) and RCP (Revenue Cap) agreements are regarded as the most representative "risk-reward" concept by being complementary applied in a BOT project (Cheah and Liu, 2006; Jun, 2008). The MRG agreement as a kind of incentive system is used to address the concerns of the private sector and to attract investor's participation in financing the project while RCP agreement is applied to protect the government from the developer's revenue exploitation in a BOT project. Although the MRG and RCP agreements are often chosen in BOT projects by both of the government and the BOT developer, the financial impact of these agreements are not well identified because the NPV analysis is not proper to evaluate these contingent claims (Cheah and Liu, 2006; Jun, 2008). However, it is fortune to have an effective alternation, the option pricing theory, in assessing the complexly combined asymmetric payoffs in real assets (Amram and Kulatilaka, 1999; Insley and Wirjanto, 2006). Similarities in evaluating process between the real assets and the financial derivatives can make possible to use the option pricing theory to evaluate the contingencies of the MRG and RCP agreements in a BOT project (Mello and Pyo, 2003; Miller and Park, 2002). So, the purpose of this paper is to suggest a theoretical and practical process to evaluate the combined financial value of the MRG and RCP agreements in a BOT project through a numerically-developed option pricing framework. To justify the applicability of the approach, the hypothetical BOT toll case is used and the results based on the model are scrutinized over those by the traditional capital budgeting theories.

\section{THEORIES}

\subsection{Traditional capital budgeting theory: NPV analysis}

The NPV analysis works well while operations are sure to generate relatively stable cash flows (Luehrman, 1997; Myers, 1984). Once risk is recognized in investment analysis based on the NPV method, the NPV analysis reflects risk through a risk-adjusted discount rate to discount the expected cash flows. In a real world, many firms classify different risk categories of projects and assign each category different rates to reflect the risk involved (Trigeorgis, 1999) or use different discount rates in different periods to reflect the change of nominal rates of interest (Aggarwal, 1993). Although the NPV analysis has been widely agreed on in various industries effective, there are also some critics as follows. First, the NPV analysis assumes that the cash outflow is stable. Even when there are cash outflows in different time periods other than time ' 0 ', they are assumed to have the same risk characteristic as the cash inflows. However, in such real assets as real estate and infrastructure projects although the future cash inflows are assumed to be certain, the uncertainty mainly comes from the cash outflows. Second, when 
the NPV analysis is applied to real assets, it can not adequately evaluate managerial flexibilities to adjust later decision when, as uncertainty is resolved, future events turn out differently from what management expected (Copeland and Antikarov, 2001; Dixit and Pindyck, 1995; Trigeorgis, 1999). Under high uncertainty, if an investment is planned with a staged decision-making or early investment reveals new information as to the future profit of the project, it deserves to invest even when NPV is negative (Amram and Kulatilaka, 1999; Trigeorgis, 1999; Dixit and Pindyck, 1994; Myers, 1984). As mistakenly ignoring the operating and managerial flexibilities involved in a project can cause a significant underestimation of its value, in the evaluation of long-term projects where future profitability is uncertain, it is critical to consider the associated managerial or strategic options (Mason and Merton, 1985). For the reasons above, the option pricing theory is suggested by some researchers as an effective method to assess the contingencies occurring in real assets incorporating the managerial flexibilities into the project value. Equation (1) describes the basic form of the NPV analysis in a way of discounting the future cash flows at a required rate of return (Brigham and Houston, 2004):

$$
N P V=-I_{0}+\sum_{i=1}^{t} F C F_{i} /(1+W A C C)^{i}
$$

where: $I_{0}$ is the initial investment; $F C F_{i}$ is the future net cash flow after tax at time (or year) $i$; WACC (Weighted Average Cost of Capital) is the required rate of return used to discount the future cash flow $F C F_{i}$, and $i$ is the time increment.

WACC of the firm or project are defined as shown in Equation (2).

$$
W A C C=R_{e}(E / A)+R_{d}(D / A)(1-T)
$$

where: $E$ is the equity; $R_{e}$ is the cost of equity; $A$ is total invested capital; $R_{d}$ is the cost of debt; $D$ is the debt, and $T$ is the corporate tax.

As for the infrastructure projects, WACC determined based on Equation (2) is used in Equation (1) to find net present value of the project. WACC stands for a company's weighted average cost of capital reflecting cost of debt and cost of equity, and it is employed to evaluate projects matching a firm's existing operational assets and associated risks (Sharpe, 1964). Thus, determining $R_{d}, T, D, E$ and $A$ is not difficult, and the last variable, cost of equity, $R_{e}$, can be often estimated by CAPM (Capital Asset Pricing Model). $R_{e}$ is a measurement of the appropriate required return that equity investors expect on equity investments, given the level of risk of such investments. Equation (3) used to estimate $R_{e}$ is based on the CAPM developed by Sharpe (1964). When it comes to the infrastructure projects, since some risk premiums coming from the uncertainties involved in the projects such as country or sector risk should be added to the cost of equity, actual risk-adjusted discount rate used in investment analysis can be greater than $R_{e}$.

$$
R_{e}=R_{f}+\beta_{e}\left(R_{m}-R_{f}\right)
$$

\subsection{Option pricing theory}

The option pricing theory developed by Black and Scholes (1973), and Merton (1973), for pricing financial derivatives is the building block of this paper. The concept of option pricing theory in finance is imported to seek to value managerial flexibilities on real assets or properties. This theory is based on the assumption that the stock price follows an uncertain diffusion process of a log-normal distribution called a 'Geometric Brownian Motio' proven to appropriately model the price of an asymmetric payoff of financial securities (Luenberger, 1998). The uncertainty of the value of real asset is reasonably reflected through this diffusion process (Brennan and Schwartz, 
1984; Dixit and Pindyck, 1994). Equation (4) describes the diffusion process of Geometric Brownian motion process in a capital market:

$$
d S / S=\mu d t+\sigma d z
$$

where: $S$ is the stock price; $\mu$ is the instantaneous rate of return; $\sigma^{2}$ is the instantaneous variance of the rate of return, and $d z$ is a random increment to a standard Wiener process.

In the option pricing theory, which falls into two folds; Black-Scholes model (continuoustime approach) and Binomial model (discretetime approach), the value of a European call option can be obtained by solving the partial differential equation derived by Black and Scholes (1973), subject to one terminal and two boundary conditions. This Black-Scholes equation is on the basis of the complex mathematical process and that is why the Black-Scholes equation is analytically limited in modeling and calculating the option. For this reason, it has been necessary to use a numerical solution such as the binomial model that this paper follows (Cox et al., 1979).

\subsection{Applying option pricing theory into infrastructure projects}

The option pricing concept has been considered in evaluating infrastructure projects. It is found crude oil price follows a mean-reverting process for a long time horizon and the managerial flexibilities contingent on oil price can be modeled with option pricing concept (Wey, 1993). Leviäkangas and Lähesmaa (2002) suggested the option approach is a useful valuation tool for intelligent transport system investments. Garvin and Cheah (2004) and Ford et al. (2002) used a option pricing approach to quantify a deferment option in a toll road project and to value the design flexibility in an engineering project respectively. Wooldridge et al. (2002) evaluated the flexibility in toll road project considering the option pricing theory with a case of Dulles
Greenway. Other works include Ho and Liu (2002) who adopted the option pricing approach to the value against equity in a BOT project by formulating a discrete-time model to reflect the stochastic processes of project value and construction cost under the condition of debt guarantee and negotiation option.

\subsection{Asymmetric payoff condition: Call and Put option}

Even if the NPV analysis is considered appropriate to evaluate the project in light of being consistent with the firm's objective to maximize the shareholders' utilities, under the uncertainty involved in an investment analysis, the discount rate used in this method needs to be fairly adjusted over the related risks based on the CAPM (Copeland and Weston, 1988). However, there is a problematic argument that the NPV analysis can not capture the characteristic of the managerial flexibilities during the uncertain behavior of the project revenue. The managerial flexibilities provide specific kinds of asymmetric payoffs analogous to those of the derivatives in a financial market. Therefore, the option pricing theory can be applied to price such complicated contingencies of the managerial flexibilities. Followings are examples of the asymmetric payoffs in financial call and put options (Hull and White, 1990).

$$
F_{\text {call }}\left(S_{t}, t\right)=\operatorname{Max}\left[0, S_{t}-X\right]
$$

and

$$
F_{\text {put }}\left(S_{t}, t\right)=\operatorname{Max}\left[0, X-S_{t}\right]
$$

where: $F_{\text {call }}$ is call option value; $F_{p u t}$ is put option value; $S_{t}$ is stock price at time $t$, and $X$ is exercise price.

\subsection{Managerial flexibilities: asymmetric payoffs of MRG and RCP agreements}

In a BOT project finance, the MRG and $\mathrm{RCP}$ agreements often used follow the riskreward concept where the higher risk requires 
higher return. As for the MRG agreement, if the realized project revenue (or cash flow) is lower than initially projected, the government should provide the developer with revenue shortfall as already agreed. This agreement, which is called "MRG", helps the government attract the developer or financial investors at the initial stage of financing. Conversely, if the project revenue is excessively surpassing the initially pre-determined level agreed on, in turn, the developer can enjoy the surplus way over it must deserve, the government should have a way to ask claim for excessive benefit so as to quit or mitigate averse situations of the revenue exploitation. This practice is called RCP agreement that stipulates the payment from the BOT developer to the government (Cheah and Liu, 2006). By nature, the exercise of both of the MRG and RCP agreements relies on the specific conditions of whether or not the projected project revenue is higher than the realized project revenue. Followings show possible asymmetric payoffs of these two agreements and the combined form of the MRG and RCP agreements, "MRC".

\section{- MRG agreement as a Put option}

When it comes to the MRG agreement, it can be formulated based on the concept of financial put option. The basic idea of the MRG agreement is that during concessionaire period if the realized cash flow in each year $i$ satisfies the projected cash flow level already signed in a contract by both of the public and the private, the government does not have to pay any MRG to the BOT developer. Otherwise, the government should compensate for the revenue shortfall by paying the BOT developer. As an MRG value, the government's obligation to pay in each year $i, S F_{i}$, would depend on the relative value between projected cash flow at year $i, C F_{i p}$, and realized cash flow at year $i, C F_{i r}$, as shown in Equation (7) (Cheah and Liu, 2006). Where, $F C F_{e}$ is free cash flow on equity at year $i$.

$$
\begin{aligned}
& S F_{i}=\operatorname{Max}\left[\text { Projected } F C F_{e} \text { at Year } i-\right. \\
& \text { Realized } \left.F C F_{e} \text { at Year } i, 0\right]=\operatorname{Max}\left[C F_{i p}-\right. \\
& \left.C F_{i r}, 0\right]
\end{aligned}
$$

Finally, we can find the MRG value as shown in Equation (8).

$$
M R G=\sum_{i=1}^{n} S F_{i} /\left(1+R_{f}\right)^{i}
$$

where: MRG is the present value of the total MRG value during concession period at time " 0 "; $R_{f}$ is the risk-free rate, and $n$ is the years of the BOT concession period.

\section{- RCP agreement as a Call option}

The RCP agreement can be formulated in a form of financial call option described in Equation (9) (Cheah and Liu, 2006). The basic concept that the RCP agreement entails is, during the concession, if the realized cash flow in each year surpasses way over negotiated level of the projected cash flow signed in a contract the government can ask claim for the revenue surplus to the BOT developer.

$$
\begin{aligned}
& R C F_{i}=\operatorname{Max}[\text { Realized } F C F e \text { at Year } i- \\
& \text { Projected } \left.F C F_{e} \text { at Year } i, 0\right]=\operatorname{Max}\left[C F_{i r}-\right. \\
& \left.C F_{i p}, 0\right]
\end{aligned}
$$

where: $R C F_{i}$ is RCP value at year $i$; $C F_{i r}$ is realized cash flow at year $i$, and $C F_{i p}$ is projected cash flow at year $i$. As an RCP value, the BOT developer's obligation to pay at year $i, R C F_{i}$, relies on the relative value between realized cash flow at year $i, C F_{i r}$, and projected cash flow at year $i, C F_{i p}$. Finally, the total value of RCP agreement until the end of concession, year $n, R C P$ can be obtained by summing up the discounted $R C F_{i}$ at risk free rate to time " 0 ". Equation (10) show this calculation process:

$$
R C P=\sum_{i=1}^{n} R C F_{i} /\left(1+R_{f}\right)^{i}
$$

When necessary to apply the MRG and $\mathrm{RCP}$ agreements in a BOT project, the way 
to specify the level of the MRG and the RCP can be based on the IRR (Internal Rate of Return), revenue, or traffic volume. And, this level would be fixed through the negotiation process between the government and the BOT developer.

\section{MRC (MRG-RCP) COMPOUND OPTION PRICING APPROACH}

This paper takes into account a development of an option pricing framework based on the binomial model (Cox et al., 1979) which is intuitive to identify the complexly-combined contingent claims; the MRG and the RCP agreements. The option modeling process keeps following disciplines. First, the MRG and the RCP agreements are numerically combined and modeled as repeatedly-exercisable compound option, MRC (MRG-RCP) option, which can be decomposed to the call and put options along with the appropriate financial and mathematical process. Second, the impact of the MRC option value on the project value is considered at the level of equity to look at the project from the BOT developer and the government's points of views. Third, the developing process of the MRC compound option model is limited to three-time step for space and mathematical complexity. Finally, the numerically-modeled MRC (MRG-RCP) option approach is tested to show enough applicability through the hypothetical case of the BOT toll system. Followings are the processes to build the MRC compound option model.

Sept 1. Underlying asset "BOT project value" and its dynamics

The first procedure to model the MRC compound option is to choose the underlying asset and its dynamics. The value change of the underlying asset, the BOT project value, affects the MRC compound option value because the option value varies contingent on the underlying asset over time (Trigeorgis, 1999). As the debt payment against the financial investors depends on the future cash flows as collateral in a project finance, the forecasted cash flow, which affects the project value, becomes a main source of the underlying asset, in turn, the uncertainty of the project value would be risky variable during the concession (Beidleman et al., 1990; Finnerty, 1996). Afterward, the project value is assumed to fluctuate over time, due to the dynamic change of market conditions until the end of the concession, with a specific diffusion process, so called "Geometric Brownian Motion” process in Equation (11) (Dixit and Pindyck, 1994).

$$
d V / V=\mu d t+\sigma d z
$$

In Equation (11), $V$ represents the market value of a completed BOT project; $\mu$ is the market required rate of return from the project; $\sigma$ describes the volatility of the rate of return in the project value, and $d z$ is an increment to a standard Wiener process. This notion helps easily assume a structure for the dynamics and uncertainties of the underlying risky asset 'BOT project value'.

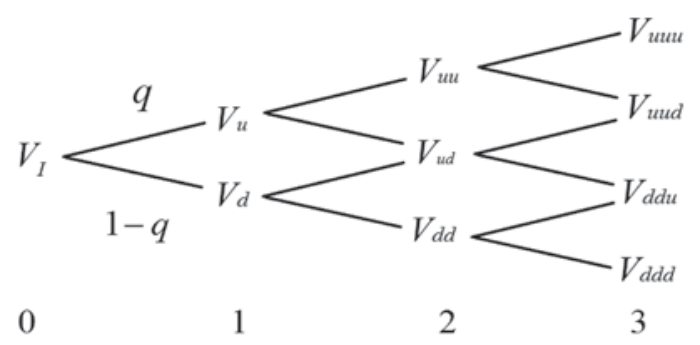

Figure 1. Binomial tree of underlying asset, $V$.

Step 2. Initial project value " $V_{I}$ "

To reflect the dynamics of the project value, it is necessary to have the initial project value identical to the discounted sum of the future cash flows but the initial investment cost, to the present with appropriate risk-adjusted discount rate. If considers the BOT developer and the government's points of views, the dynamics 
of the project value on equity can be shown in Equation (12).

$$
V_{I}=\sum_{i=1}^{n} F C F e_{i} /\left(1+R_{e}\right)^{i}
$$

where: $\mathrm{FCFe}_{i}$ is the free cash flow on equity at year $i$ and $R_{e}$ is the cost of equity. $F C F e_{i}$ is obtained by deducting the annual debt service from the annual free cash flows.

\section{Step 3. Volatility " $\sigma$ "}

Volatility, $\sigma$, defined as a standard deviation of rate of return in cash flow return is a measurement of the 'risk' in finance and considered as an important factor to dominate the option value (Brigham and Houston, 2004; Hull, 1997). There exist some ways; Logarithmic cash flow return approach, Monte Carlo simulation, implied volatility, and so on, to find this value and, according to the extent required for each financial analysis; level of the accuracy or the convenience, the financial modeler chooses the method believed proper. Amongst various methodologies to find the volatility, because the logarithmic cash flow return approach is considered easy to be simply applied in a financial analysis, it is widely used in the valuation of real assets in many industries (Jun, 2008). The basic data used to calculate the volatility may be historic or future estimates of cash flow returns agreed between the public and the private in a project. In the BOT case example in this paper, it is assumed that the volatility is given for space and the convenience of the calculation.

Step 4. Up and down movements \& risk neutral probabilities

In the project value change over time, "up" and "down" movements, $u$ and $d$, which are multiplied with the initial project value $V I$ to reflect the uncertain behavior of the project value, are obtained from Equation (13) and (14) with $\sigma$. By imposing $u=1 / d$ for convenience, the up and down movements " $u$ " and " $d$ " and risk neutral probabilities " $q$ " and " $1-q$ " can be obtained from Equation (15) to (16) (Cox et al., 1979). When we say $n$ is number of times that one period of time is divided and $\Delta t$ is time interval, $n$ multiplied by $\Delta t$ equals to 1 .

$$
u=\operatorname{Exp}[\sigma \sqrt{\Delta t}]
$$

and

$$
\begin{aligned}
& d=\operatorname{Exp}[-\sigma \sqrt{\Delta t}] \\
& q=R-d / u-d
\end{aligned}
$$

and

$$
1-q=u-R / u-d
$$

where: $u$ and $d$ are up and down movement multipliers of project value respectively and $R$ is multiplier of risk-free rate, while continuous time approach.

However, it can be considered to obtain $u$ and $d$ under the assumptions that the riskneutral probabilities $q$ and $1-q$ are equal to 0.5 for the convenience of the calculation (Hull, 1997). By keeping the risk-neutral probabilities stable, it becomes trivial whether the binomial tree is huge and the calculation is heavy regardless of the number of time step (Hull, 1997). Equation (17) and (18) are the replacements of Equation (13) and (14) while $q$ and $1-q$ equal to 0.5 .

$$
u=\operatorname{Exp}\left[\left(r-(1 / 2) \sigma^{2}\right) \Delta t+\sigma \sqrt{\Delta t}\right]
$$

and

$$
d=\operatorname{Exp}\left[\left(r-(1 / 2) \sigma^{2}\right) \Delta t-\sigma \sqrt{\Delta t}\right]
$$

The financial implication of risk-neutral probabilities is that the world where the project is being implemented is risk-neutral so that the financial modeler does not have to waste their time to find any arbitrary risk-adjusted discount rate (Jun, 2008). The notion of this "risk-neutral world" that the option pricing theory is based on in financial economics is tremendously helpful while the use of the 
financial engineering technique in evaluating complex financial products such as option, future, derivatives (Copeland and Antikarov, 2001).

Step 5. Binomial tree with an underlying asset " $V$ "

This is time to build a binomial tree, with parameters taken from above steps, which stands for all likely project values under the uncertainty. As shown in Figure 1, since the binomial tree reflects all the likely project values considering the uncertainty over time, the project values shown in the binomial tree represents the realized project values. Equation (19) to (27) are the realized project values in detail.

$$
\begin{aligned}
& A t t=1 \\
& V_{u}=u V_{I}=\operatorname{Exp}\left[1 \cdot \left(\left(r-(1 / 2) \sigma^{2}\right) \Delta t+\right.\right. \\
& \sigma \sqrt{\Delta t})] V_{I} \\
& V_{d}=d V_{I}=\operatorname{Exp}\left[1 \cdot \left(\left(r-(1 / 2) \sigma^{2}\right) \Delta t-\right.\right. \\
& \sigma \sqrt{\Delta t})] V_{I} \\
& A t t=2 \\
& V_{u u}=u^{2} V_{I}=\operatorname{Exp}\left[2 \cdot \left(\left(r-(1 / 2) \sigma^{2}\right) .\right.\right. \\
& \Delta t+\sigma \sqrt{\Delta t})] V_{I} \\
& V_{u d}=u d V_{I}=\operatorname{Exp}\left[1 \cdot \left(\left(r-(1 / 2) \sigma^{2}\right) \Delta t+\right.\right. \\
& \left.\sigma \sqrt{\Delta t})+1 \cdot\left(\left(r-(1 / 2) \sigma^{2}\right) \Delta t-\sigma \sqrt{\Delta t}\right)\right] V_{I} \\
& V_{d d}=d^{2} V_{I}=\operatorname{Exp}\left[2 \cdot \left(\left(r-(1 / 2) \sigma^{2}\right) \Delta t-\right.\right. \\
& \sigma \sqrt{\Delta t})] V_{I} \\
& A t t=3 \\
& V_{u u u}=u^{3} V_{I}=\operatorname{Exp}\left[3 \cdot \left(\left(r-(1 / 2) \sigma^{2}\right) \Delta t+\right.\right. \\
& \sigma \sqrt{\Delta t})] V_{I}
\end{aligned}
$$

$$
\begin{aligned}
& V_{u u d}=u^{2} d V_{I}=\operatorname{Exp}\left[2 \cdot \left(\left(r-(1 / 2) \sigma^{2}\right) \Delta t+\right.\right. \\
& \left.\sigma \sqrt{\Delta t})+1 \cdot\left(\left(r-(1 / 2) \sigma^{2}\right) \Delta t-\sigma \sqrt{\Delta t}\right)\right] V_{I} \\
& V_{d d u}=d^{2} u V_{I}=\operatorname{Exp}\left[2 \cdot \left(\left(r-(1 / 2) \sigma^{2}\right) \Delta t-\right.\right. \\
& \left.\sigma \sqrt{\Delta t})+1 \cdot\left(\left(r-(1 / 2) \sigma^{2}\right) \Delta t+\sigma \sqrt{\Delta t}\right)\right] V_{I} \\
& V_{d d d}=d^{3} V_{I}=\operatorname{Exp}\left[3 \cdot \left(\left(r-(1 / 2) \sigma^{2}\right) \Delta t-\right.\right. \\
& \sigma \sqrt{\Delta t})] V_{I}
\end{aligned}
$$

\section{Step 6. Option formulation}

Firstly, the MRG agreement can be considered to be formulated as a repeatedly exercisable put option based on the asymmetric payoff condition in Equation (7). However, this paper takes into account the option pricing frame at the level of project value as shown in Equation (28) because the volatility we need based on the project value is not exactly identical to that by the cash flow. If the realized project value at each time step is higher than the projected project value, there is no reason for the government to pay the MRG to developer. On the other hand, if the realized project value is less than the projected project value, there should be an MRG for the developers to quit an averse condition where they can not obtain the minimum revenue to cover the cost, expense, or debt.

$$
\begin{aligned}
& M R G_{i}=\text { Max }[\text { Projected Project Value on } \\
& \text { Equity at Year } i-\text { Realized Project Value } \\
& \text { on Equity at Year } i, 0]
\end{aligned}
$$

Conversely, to numerically formulate the $\mathrm{RCP}$ agreement, the concept of the repeatedly exercisable call option in Equation (29) is taken into account. Like in the formulation of the MRG agreement, the RCP agreement is modeled at the level of project value as well. The asymmetric payoff generated from the RCP agreement during the concession is as below. 
$R C P_{i}=$ Max $[$ Realized Project Value on

Equity at Year $i$ - Projected Project Value

on Equity at Year $i, 0]$

where: $R C P_{i}$ is the RCP value at year $i$.

Finally, because the MRC compound option needs to reflect the characteristics of both of the MRG and the RCP agreements, the MRC option is modeled by combining the Equation (28) and (29). So, Equation (30) is the final form of the asymmetric payoff in the MRC compound option. $M R C_{i}$ represents the MRC value at year $i$ and this option is repeatedly exercisable call-put compound option.

$M R C_{i}=$ Max $[$ Projected Project Value on

Equity at Year $i$ - Realized Project Value

on Equity at Year i, Realized Project Value

on Equity at Year $i$ - Projected Project

Value on Equity at Year $i, 0]$

As for the exercise price, recall that the project value change in the option pricing theory follows a geometric Brownian motion process contingent on two major factors: the term of the stable rate of return which excludes the possibility of uncertain price behavior and that of the uncertain rate of return which follows random selection process during the operation (Hull and White, 1990). Here, the varying project value with the stable rate of return is assumed as a realized project value "exercise price" as described in Equation (31). $X_{n}$ represents an exercise price at time $t$.

$$
\begin{aligned}
& \text { At } t=n \\
& X_{n}=\operatorname{Exp}\left[n \cdot\left(r-(1 / 2) \sigma^{2}\right) \Delta t\right] V_{I}
\end{aligned}
$$

Step 7. Asymmetric payoff condition at each node in the binomial tree

Throughout the above steps, we finally can construct the asymmetric payoff conditions in a form of the binomial tree for each time step as shown in Figure 2. As for the asymmetric payoffs for all node of the binomial tree, $M R C u$ and $M R C d$, at $t=1$, are $\operatorname{Max}\left[X_{1}-V_{u}, V_{u}-X_{1}, 0\right]$ and $\operatorname{Max}\left[X_{1}-V_{d}, V_{d}-X_{1}, 0\right]$ respectively. A $t=2$, $M R C_{u u}, M R C_{u d}$, and $M R C_{d d}$ are $\operatorname{Max}\left[X_{2}-\right.$ $\left.V_{u u}, V_{u u}-X_{2}, 0\right], \operatorname{Max}\left[X_{2}-V_{u d}, V_{u d}-X_{2}, 0\right]$, and $\operatorname{Max}\left[X_{2}-V_{d d}, V_{d d}-X_{2}, 0\right]$ respectively. At $t=3, M R C_{u u u}, M R C_{u u d}, M R C_{d d u}$, and $M R C_{d d d}$ are $\operatorname{Max}\left[X_{3}-V_{\text {uиu }}, V_{\text {uиu }}-X_{3}, 0\right]$, $\operatorname{Max}\left[X_{3}-V_{u u d}, V_{\text {uud }}-X_{3}, 0\right], \operatorname{Max}\left[X_{3}-V_{d d u}\right.$, $\left.V_{d d u}-X_{3}, 0\right]$, and $\operatorname{Max}\left[X_{3}-V_{d d d}, V_{d d d}-X_{3}, 0\right]$ respectively.

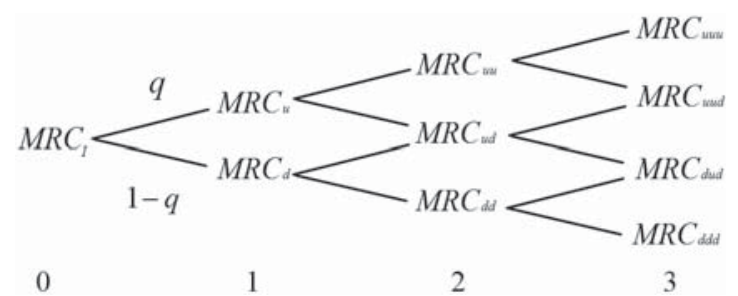

Figure 2. Asymmetric payoff of the MRC compound option in binomial tree.

\section{Step 8. MRC compound option value calculation}

As the final step of modeling the MRC compound option, the calculation of option value begins from the back of the binomial tree recursively in Figure 2. The selected option value based on the asymmetric payoff condition at every node can be calculated with the parameters of $q, 1-q$, and $R$. For instance, while finding the option value $M R C u u$ at node "uu" in Figure 2, we can expect two events of whether an MRC compound option is exercised or not as below in Equation (32) which shows two likely events at node "uu".

$\operatorname{MRC}_{u u}\left\{\begin{array}{c}\text { Not Exercised: }\left[q \operatorname{Max}\left[X_{3}-V_{u u u}, V_{u u u}-X_{3}, 0\right]+(1-q) \operatorname{Max}\left[X_{3}-V_{u u d}, V_{u u d}-X_{3}, 0\right]\right] / \operatorname{Exp}[r \Delta t] \\ \text { Exercised: } \operatorname{Max}\left[X_{2}-V_{u u}, V_{u u}-X_{2}, 0\right]\end{array}\right.$ 
Afterward, as we should selectively choose the maximized option value at every node under the assumption that the reasonable investors do their best to maximize profits, the larger option value regardless of option's exercise will be selected (Copeland and Antikarov, 2001; Jun, 2008). Hence, the only one chosen between two option values whichever is larger is the very option value at node " $u u$ ". Equation (33) describes the MRC value at node "uu".

$$
\begin{aligned}
& \operatorname{MRC}_{u u}=\operatorname{Max}\left[\left[q \operatorname { M a x } \left[X_{3}-V_{u u u},\right.\right.\right. \\
& \left.V_{u u u}-X_{3}, 0\right]+(1-q) \operatorname{Max}\left[X_{3}-V_{u u d},\right. \\
& \left.\left.V_{u u d}-X_{3}, 0\right]\right] / \operatorname{Exp}[r \Delta t], \\
& \left.\operatorname{Max}\left[X_{2}-V_{u u}, V_{u u}-X_{2}, 0\right]\right]
\end{aligned}
$$

Equation (34) to (39) describes all likely MRC option values at all nodes in the threestep binomial tree and, through the iterations of this process at every node for all time steps, the $M R C$ value at time " 0 ", which finally we want to have, can be calculated (the $M R C$ values of $M R C_{u u u}, M R C_{u u d}, M R C_{d d u}$, and $M R C_{d d d}$ at $t=3$, are $\operatorname{Max}\left[X_{3}-V_{\text {uuu }}, V_{\text {uиu }}-\right.$ $\left.X_{3}, 0\right], \operatorname{Max}\left[X_{3}-V_{u u d}, V_{u u d}-X_{3}, 0\right], \operatorname{Max}\left[X_{3}-\right.$ $\left.V_{d d u}, V_{d d u}-X_{3},{ }_{0}\right]$, and $\operatorname{Max}\left[X_{3}-V_{d d d}, V_{d d d}-\right.$ $\left.X_{3}, 0\right]$ respectively because this is the final time step).

$$
\begin{aligned}
& \text { At } t=2 \\
& M R C_{u u}=\operatorname{Max}\left[\left[q M R C_{u u u}+\right.\right. \\
& \left.(1-q) M R C_{u u d}\right] / \operatorname{Exp}[r \Delta t], \operatorname{Max}\left[X_{2}-V_{u u}\right. \\
& \left.\left.V_{u u}-X_{2}, 0\right]\right] \\
& M R C_{u d}=\operatorname{Max}\left[\left[q M R C_{u d u}+\right.\right. \\
& \left.(1-q) M R C_{u d d}\right] / \operatorname{Exp}[r \Delta t], \operatorname{Max}\left[X_{2}-V_{u d}\right. \\
& \left.\left.V_{u d}-X_{2}, 0\right]\right]
\end{aligned}
$$

$$
\begin{aligned}
& M R C_{d d}=\operatorname{Max}\left[\left[q M R C_{d d u}+\right.\right. \\
& \left.(1-q) M R C_{d d d}\right] / \operatorname{Exp}[r \Delta t], \operatorname{Max}\left[X_{2}-V_{d d},\right. \\
& \left.\left.V_{d d}-X_{2}, 0\right]\right] \\
& \text { At } t=1 \\
& M R C_{u}=\operatorname{Max}\left[\left[q M R C_{u u}+(1-q) M R C_{u d}\right] /\right. \\
& \left.\operatorname{Exp}[r \Delta t], \operatorname{Max}\left[X_{1}-V_{u}, V_{u}-X_{1}, 0\right]\right] \\
& M R C_{d}=\operatorname{Max}\left[\left[q M R C_{d u}+(1-q) M R C_{d d}\right] /\right. \\
& \left.\operatorname{Exp}[r \Delta t], \operatorname{Max}\left[X_{2}-V_{d}, V_{d}-X_{2}, 0\right]\right] \\
& \text { At } t=0 \\
& M R C=\left[q M R C_{u}+(1-q) M R C_{d}\right] / \operatorname{Exp}[r \Delta t]= \\
& \operatorname{Max}\left[\left[q \operatorname { M a x } \left[\left[q M R C_{u u}+(1-q) M R C_{u d}\right] /\right.\right.\right. \\
& \left.\operatorname{Exp}[r \Delta t], X_{1}-V_{u}, V_{u}-X_{1}, 0\right]+(1-q)^{\circ} \\
& \operatorname{Max}\left[\left[q M R C_{d u}+(1-q) M R C_{d d} / \operatorname{Exp}[r \Delta t]\right],\right. \\
& \left.\left.\left.X_{1}-V_{d}, V_{d}-X_{1}, 0\right]\right] / \operatorname{Exp}[r \Delta t]\right]
\end{aligned}
$$

\section{HYPOTHETICAL BOT CASE STUDY}

This chapter is to apply the MRC compound option pricing framework into the hypothetical case of the BOT toll road, which is simplified version of a real project, to show the applicability of the approach. Table 1 describes the basic data and information of the BOT case example where the capital expenditure, operating expenditure, and average toll rate are assumed to increase at annual level of $3 \%$. The initial traffic volume and the traffic volume growth rate are assumed to follow log-normal and normal distributions respectively (Cheah and Liu, 2006). Table 2 describes the expected cash flow model given data and information in Table 1. 
Table 1. Hypothetical BOT toll road case

\begin{tabular}{llll}
\hline \multicolumn{2}{l}{ Capital structure (\$: Dollars, M: Million) } & & \\
\hline Project construction cost & $\$ 143.47 \mathrm{M}(3$ years) & Average toll rate & $\$ 1.87$ \\
Debt : Equity $=71.8: 28.2$ & $\$ 103.01 \mathrm{M}: \$ 40.46 \mathrm{M}$ & Concession period & $\begin{array}{l}30 \text { years (from 2005) } \\
90 \% \text { of expected revenue } \\
\text { (30 years) }\end{array}$ \\
Debt & Senior: 13 years $(7.25 \%)$ & MRG agreement & $\begin{array}{l}110 \% \text { of expected revenue } \\
(30 \text { years) }\end{array}$ \\
Capital expenditure & $\$ 2.61 \mathrm{M}$ (every 5 years) & RCP agreement & $10.4 \%$ \\
Operating expenditure & $\$ 2.59 \mathrm{M}$ (every year) & Market rate of return & $5.3 \%$ \\
Corporate tax rate & $27.5 \%$ & Risk free rate & $12.848 \%$ \\
$\begin{array}{l}\text { Initial traffic volume/ } \\
\text { Volatility }\end{array}$ & $7.153 / 1.94 \mathrm{M}$ (year) & Cost of equity & \\
$\begin{array}{l}\text { Traffic volume growth rate/ } \\
\text { Volatility }\end{array}$ & $2.34 / 0.79 \%$ & Volatility & 0.083 \\
\hline
\end{tabular}

Table 2. Expected cash flow of hypothetical BOT toll road case (\$: Dollar, M: Million)

\begin{tabular}{llllllllllll}
\hline Year & 2002 & 2003 & 2004 & 2005 & 2006 & $\ldots$ & $\ldots$ & $\ldots$ & 2032 & 2033 & 2034 \\
\hline Traffic volume $(\mathrm{M})$ & - & - & - & 7.153 & 7.398 & $\ldots$ & $\ldots$ & $\ldots$ & 13.381 & 13.668 & 13.962 \\
Toll rate $(\$)$ & - & - & - & 1.87 & 1.93 & $\ldots$ & $\ldots$ & $\ldots$ & 4.16 & 4.29 & 4.42 \\
\hline Gross revenue $(\mathrm{M}, \$)$ & - & - & - & 13.40 & 14.28 & $\ldots$ & $\ldots$ & $\ldots$ & 55.69 & 58.59 & 61.65 \\
CAPEX $(\mathrm{M}, \$)$ & 40.46 & - & - & & & $\ldots$ & $\ldots$ & $\ldots$ & & 5.96 \\
OPEX $(\mathrm{M}, \$)$ & - & - & - & 2.50 & 2.58 & $\ldots$ & $\ldots$ & $\ldots$ & 5.55 & 5.72 & 5.89 \\
EBIT $(\mathrm{M}, \$)$ & -40.46 & - & - & 10.90 & 11.70 & $\ldots$ & $\ldots$ & $\ldots$ & 50.14 & 52.87 & 49.80 \\
Debt service $(\mathrm{M}, \$)$ & - & - & - & & & $\ldots$ & $\ldots$ & $\ldots$ & & & \\
Taxes $(\mathrm{M}, \$)$ & - & - & - & 3.00 & 3.22 & $\ldots$ & $\ldots$ & $\ldots$ & 13.79 & 14.54 & 13.69 \\
\hline FCF on equity $(\mathrm{M}, \$)$ & -40.46 & - & - & 7.90 & 8.48 & $\ldots$ & $\ldots$ & $\ldots$ & 36.35 & 38.33 & 36.10 \\
\hline
\end{tabular}

\subsection{NPV analysis}

With market risk premium, $R_{m}-R_{f}$ of $5.1 \%, \beta_{e}$ of 1.48 which is the weighted average of the equity investors' $\beta$, and the given data shown in Table 1 , we finally find $N P V_{e}$ equal to $\$ 2.02$ million without considering the impact of the MRG and RCP agreements. Equation (40) and (41) show how re and $N P V_{e}$ are obtained.

$$
\begin{aligned}
& R_{e}=R_{f}+\left(R_{m}-R_{f}\right) \beta_{e}=5.3 \%+ \\
& (5.1 \times 1.48)=12.848 \%
\end{aligned}
$$

$$
\begin{aligned}
& N P V_{e}=-40.46 /(1.1285)^{0}+0.0 /(1.1285)^{1}+ \\
& 0.0 /(1.1285)^{2}+\ldots+38.33 /(1.1285)^{31}+ \\
& 36.10 /(1.1285)^{32}=\$ 2.02 \text { Million }
\end{aligned}
$$

\subsection{Option pricing analysis}

We can obtain some calculated parameters of $V_{I}, \sigma, u, d, q$, and 1-q, based on the steps described earlier, necessary to be ready for the option pricing approach and building a binomial tree to render all the likely project values 
supposed to happen during the concession. The initial project value $V_{I}$ is as Equation (42).

$$
\begin{aligned}
& V_{I}=\sum_{i=1}^{n} F C F_{e i} /\left(1+R_{e}\right)^{i}=7.90 /(1.1285)^{1}+ \\
& 8.48 /(1.1285)^{2}+\ldots+38.33 /(1.1285)^{29}+ \\
& 36.10 /(1.1285)^{30}=\$ 54.10 \text { Million }
\end{aligned}
$$

Given that the volatility of the project value is 0.083 in Table 1, we can calculate the up and down movements of $u$ and $d$. When $\Delta t$ and $n$ equal to $1, u$ is obtained by $\operatorname{Exp}[(0.053-(1 / 2)$ $\left.\left.(0.083)^{2}\right) \times 1+(0.083 \sqrt{1})\right]$. Then the result is 1.142. $d$ also can be obtained by the formula of $\operatorname{Exp}\left[\left(0.053-(1 / 2)(0.083)^{2}\right) \times 1-(0.083 \sqrt{1})\right]$. Finally, $d$ is 0.967 . As for the exercise price, $X$, dependent on the projected project value, since the projected project value at time ' 0 ' is the same as the initial project value multiplied by 1.1 according to the agreement the revenue surplus which is way over $110 \%$ of the expected cash flow will be paid back to the government, the initial exercise price is $1.1 \times 54.10$ identical to 59.51 at the first year of the operation. Afterward, this value increases at annual rate of $r-(1 / 2) \sigma^{2}=0.053-(1 / 2) 0.083^{2}=0.05$ over time from second year of the concession. The MRC value is obtained from backward recursive calculation process by being discounted at risk-free rate with the consideration of risk neutral probabilities regardless of whether or not the option is exercised at every node in the binomial tree. As a result, the calculation gives us the MRC value, in 2007, $\$ 19.50$ million as described in Table 3.

\section{RESULTS}

The MRC value in 2002 is $\$ 17.54$ million, by discounting the MRC value in 2004, $\$ 19.50$ million, at risk-free rate. This accounts for $868 \%$ of $N P V_{e}, \$ 2.02$ million, and $43.85 \%$ of the equity investment, $\$ 40$ million, respectively. The result shows the combined effect of the MRG and RCP agreements can not be ignored because of its huge impact on the project value. Figure 3 and 4 and Table 4 describe the sensitivity of the MRC value to the change of the volatilities of two revenue components. The result renders while the MRC value relies on the volatility of the initial traffic volume, the volatility of the traffic volume growth rate does not seem to impact on the MRC value. This implies that for the government and the BOT developer to reasonably decide the MRG and RCP levels during the bidding process, they have to more focus on predicting the probability distribution of the initial traffic volume rather than that of the traffic volume growth rate. Another needs to be better emphasized is the MRC value against the volatility of the project value (underlying asset) behaves the same way as the financial option where the option value increases while the volatility of the underlying asset grows. As for the effect of the MRG level on the project MRC value, it turns out the increase of the MRG level increases the MRC value in Figure 5. Conversely, the increasing revenue ceiling seems to reduce the MRC value as the probability of the threshold to exercise the RCP option becomes lower in Figure 6. Therefore, the BOT developer tends to make the MRG and RCP levels stay higher while the government must run counter by lowering the MRG and RCP levels not to be exploited in the project revenue. Here, as the projected project value used as an exercise price is the only controllable factor on which the MRG and RCP levels depend, the process to decide these thresholds should be also carefully dealt with. Finally, the wise use of the information captured by this model can help both of the government and the BOT developer put themselves in an advantageous position in their bidding process. 


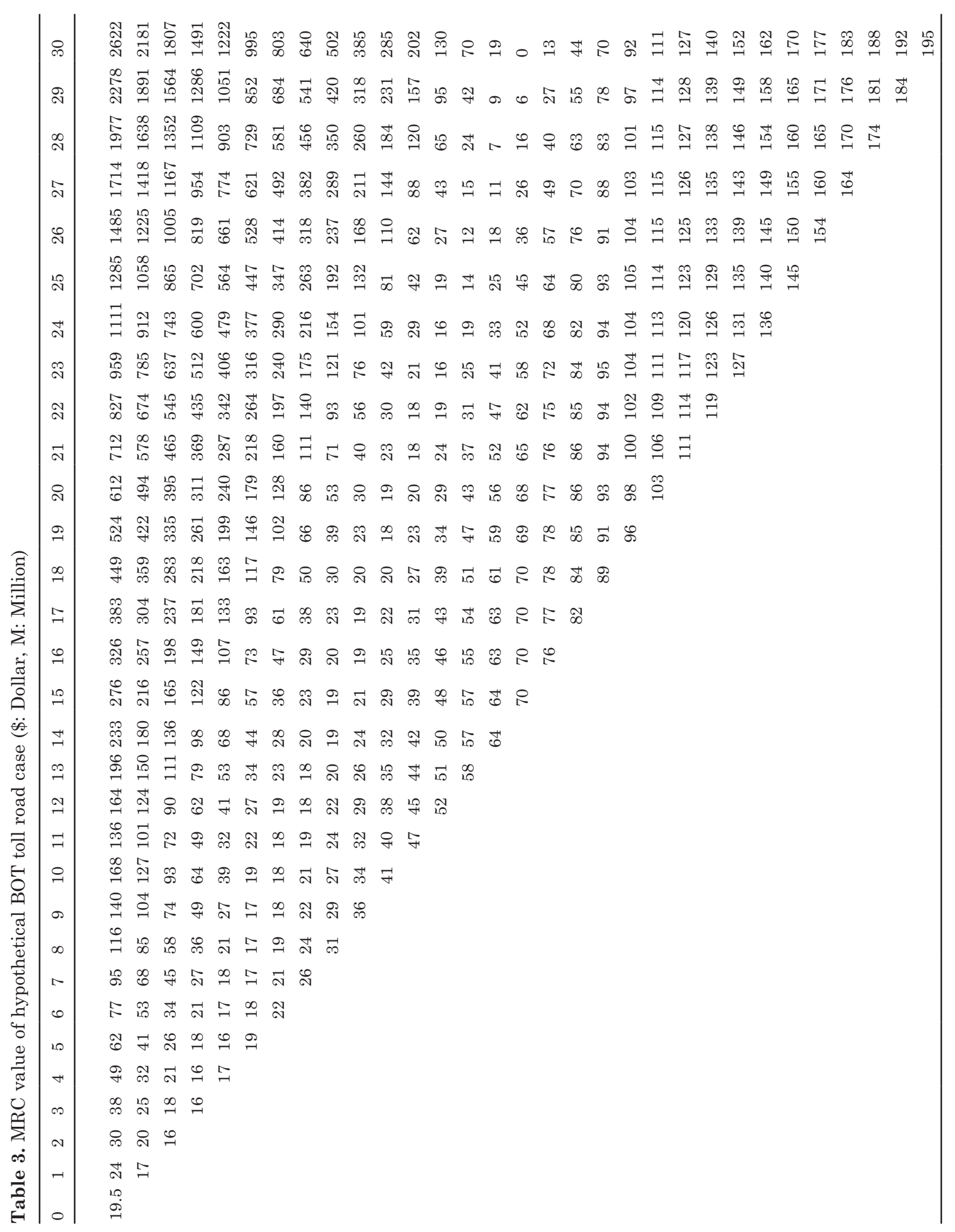


Table 4. "Volatility of project value" and "MRC value" against the volatility of revenue components

\begin{tabular}{|c|c|c|c|c|c|}
\hline \multirow{2}{*}{$\begin{array}{l}\text { MRC value } \\
\text { (Volatility of project value) }\end{array}$} & \multicolumn{5}{|c|}{ Volatility of traffic volume growth rate ( $\sigma \mathrm{GR})$} \\
\hline & & 0.40 & 0.79 & 1.19 & 1.58 \\
\hline \multirow{4}{*}{$\begin{array}{l}\text { Volatility of initial traffic } \\
\text { volume ( } \sigma \mathrm{TV})\end{array}$} & 0.97 & $8.16(0.042)$ & 7.94(0.041) & 7.94(0.041) & 7.94(0.041) \\
\hline & 1.94 & $16.81(0.080)$ & $17.54(0.083)$ & $16.81(0.080)$ & $17.05(0.081)$ \\
\hline & 2.91 & $25.80(0.117)$ & $25.80(0.117)$ & 26.05(0.118) & $25.80(0.117)$ \\
\hline & 3.88 & $34.24(0.152)$ & $33.76(0.150)$ & $34.24(0.152)$ & $34.24(0.152)$ \\
\hline
\end{tabular}

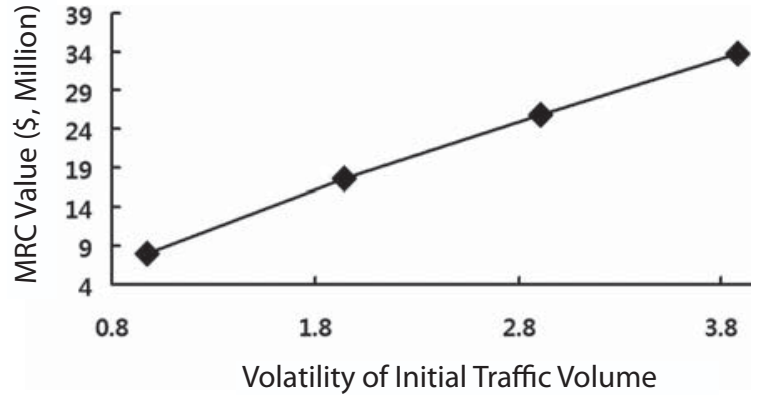

Figure 3. Sensitivity of the MRC value to volatility of initial traffic volume ( $\sigma \mathrm{GR}: 0.79$ ).

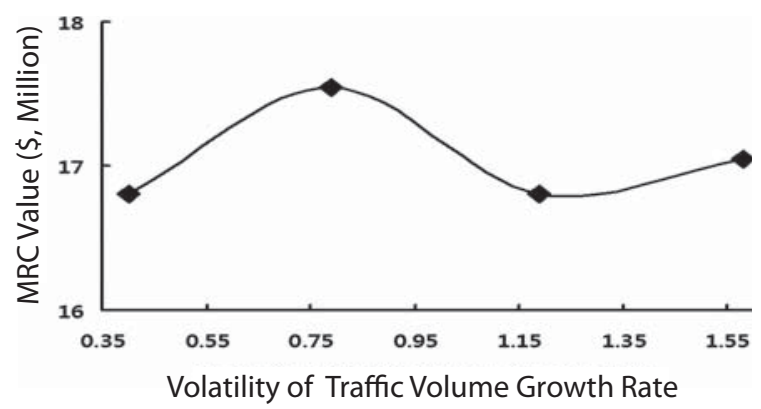

Figure 4. Sensitivity of the MRC value to volatility of traffic volume growth rate (oTV: 1.94).

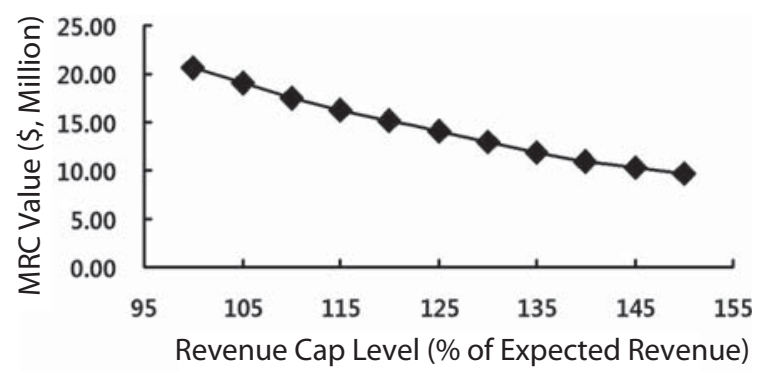

Figure 5. MRC value over MRG level (RCP: 90\%).

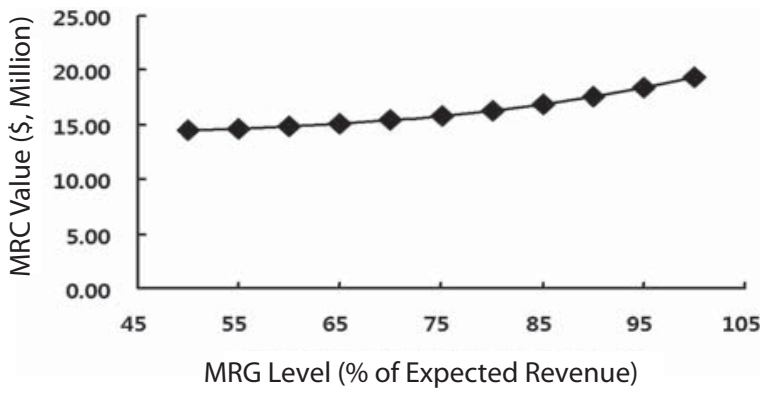

Figure 6. MRC value over revenue cap level (MRG: 110\%).

\section{CONCLUSIONS}

The MRG and RCP agreements are important concerns for both of the BOT developer and the government during the BOT project because the use of these two agreements are often simultaneously selected in a bidding process to hedge the risks due to the operational risk in light of the risk-reward concept and have been known to impact on the financial feasibility of the project. However, the applications of the MRG and RCP agreements produce kind of complex contingencies to make difficult to assess the project value with the NPV analysis. So, the option pricing framework to evaluate the MRC compound option combined with the MRG and RCP agreements is modeled in this paper and, at last, following meaningful conclusions are drawn from. First, the MRC option value appears to significantly impact on the net present value on equity and 
the initial equity investment in the BOT toll case. Therefore, appropriately agreed MRG and RCP levels in a BOT project play an important role for both of the BOT developer and the government to feel comfortable under the operational uncertainty should things go wrong. Second, in a bidding process, the government may seek to lower the MRG and RCP levels while the BOT developer may do quite the opposite within agreeable range. However, the level of the RCP and MRG agreements should be fairly balanced with the notion that the reward needs to correspond to the risk level involved. So, the option pricing approach can be an efficient alternation to suggest the fairly quantified the MRG and RCP agreement levels. Third, the option approach formulated in this paper seems relatively easy to use in a real BOT project rather than the Black-Scholes model because its derivation comes from simple algebra. In addition, the way to formulate the MRC compound option may be applied to assess other complex managerial flexibilities in a BOT project through the adequate modification process. However, in this paper there are still some open issues that mainly arise from the characteristics of the BOT project or the option pricing theory. Therefore, it is supposed to further investigations concerning the followings. First, the only reasonable financial modeling for a BOT project can justify the credibility of the MRC option value. Whatever the purpose is, if the project revenue is intentionally distorted, the option value may go far beyond the reasonable range, in turn, change the result of the negotiation. So, further empirical studies are essential to improve the fundamental of the option pricing frame in the BOT project world. Second, for both of the government and the BOT developer to identify the admissible levels of the MRG and RCP agreements considering the risk-reward concept, it needs to investigate how balanced the RCP (or MRG) value is with that of the MRG (or RCP) by matching two agreement values. Even though this process seems to require further research to separately model and evaluate the MRG and RCP agreements, it can help understand the additive impact of the MRC compound option, which is mixed with the MRG and RCP agreements, on the project value relative to the separate impact of the MRG and the RCP options. And, it is no doubt that this process is meaningful for the government and the BOT developer to build strategic bidding plans. At last, in a real world, since there are more various and complicated managerial flexibilities able to be formed as asymmetric payoffs, effort to identify, formulate, and evaluate these contingencies is more required.

\section{REFERENCES}

Aggarwal, R. (1993) Capital budgeting under uncertainty: new and advanced perspectives, Englewood Cliffs, NJ: Prentice Hall.

Amram, M. and Kulatilaka, N. (1999) Real options: managing strategic investment in an uncertain world, Cambridge, MA: Harvard Business School Press.

Beidleman, C.R., Fletcher, D. and Veshosdy, D. (1990) On allocating risk: the essence of project finance, Sloan Management Review, 31, pp. 47-55.

Black, F. and Scholes, M. (1973) The pricing of options and corporate liabilities, Journal of Political Economy, 81(3), pp. 637-654. doi:10.1086/260062

Brennan, M.J. and Schwartz, E.S. (1984) Optimal financial policy and firm valuation, Journal of Finance, 39(3), pp. 593-607. doi:10.2307/2327917

Brigham, E.F. and Houston, J.F. ( 2004) Fundamentals of financial management (10 $0^{\text {th }}$ ed.), Mason, $\mathrm{OH}$ : Thompson South-Western.

Cheah, C.Y.J. and Liu, J. (2006) Valuing governmental support in infrastructure projects as real options using Monte Carlo simulation, Construction Management and Economics, 24(2), pp. 545-554. doi:10.1080/01446190500435572

Copeland, T.E. and Antikarov, V. (2001) Real options: a practitioner's guide, New York: Texere LLC. 
Copeland, T.E. and Weston, J.F. (1988) Financial theory and corporate policy, New York: Addison-Wesley.

Cox, J.C., Ross, S.A. and Rubinstein, M. (1979) Option pricing: a simplified approach, Journal of Financial Economics, 7(3), pp. 229-263. doi:10.1016/0304-405X(79)90015-1

Dixit, A.K. and Pindyck, R.S. (1994) Investment under uncertainty, Princeton, NJ: Princeton University Press.

Dixit, A.K. and Pindyck, R.S. (1995) The options approach to capital investment, Harvard Business Review, (May-June), pp. 105-115.

Finnerty, J.D. (1996) Project financing: asset-based financial engineering, New York: John Wiley \& Sons, Inc.

Ford, D., Lander, D. and Voyer, J. (2002) A real option approach to valuing strategic flexibility in uncertain construction projects, Construction Management and Economics, 20(4), pp. 343-351. doi:10.1080/01446190210125572

Garvin, M.J. and Cheah, Y.J. (2004) Valuation techniques for infrastructure investment decisions, Construction Management and Economics, 22(4), pp. 373-383. doi:10.1080/01446190310001649010

Ho, S.P. and Liu, L.Y. (2002) An option pricingbased model for evaluating the financial viability of privatized infrastructure projects, Construction Management and Economics, 20(2), pp. 143-156. doi:10.1080/01446190110110533

Hull, J. and White, A. (1990) Valuing derivative securities using the explicit finite difference method, Journal of Financial and Quantitative Analysis, 25(1), pp. 87-100. doi:10.2307/2330889

Hull, J. (1997) Options, futures, and other derivatives ( $3^{r d}$ ed.), Englewood Cliffs, NJ: Prentice Hall.

Insley, M.C. and Wirjanto, T.S. (2006) Contrasting two approaches in real options valuation-contingent claims versus dynamic programming, Working Paper. U.S.: University of Waterloo.

Jun, Jae Bum (2008) Valuation of governmental guarantee in BOT project finance with real option analysis. Ph.D. Texas A\&M University.
Leviäkangas, P. and Lähesmaa, J. (2002) Profitability evaluation of intelligent transport system investments, Journal of Transportation Engineering-ASCE, 128(3), pp. 276-286. doi:10.1061/(ASCE)0733-947X(2002)128:3(276)

Luehrman, T. (1997) What's it worth? A general manager's guide to valuation, Harvard Business Review, 75(3), pp. 132-142.

Luenberger, D. (1998) Investment science, N.Y.: Oxford University Press.

Mason, S.P. and Merton, R.C. (1985) The role of contingent claims analysis in corporate finance. Recent advances in corporate finance, edited by Altman, E.I. and M.G. Subrahmanyam, Homewood, IL: Richard D. Irwin Inc.

Mello, A.S. and Pyo, U. (2003) Real options with market risks and private risks, Journal of Applied Corporate Finance, 15(2), pp. 89-101. doi:10.1111/j.1745-6622.2002.tb00699.x

Merton, R.C. (1973) Theory of rational option pricing, Bell Journal of Economics and Management Science, 4, pp. 141-183. doi:10.2307/3003143

Miller, L.T. and Park, C.S. (2002) Decision making under uncertainty-real options to the rescue, The Engineering Economist, 47(2), pp. 105-150. doi:10.1080/00137910208965029

Myers, S.C. (1984) Finance theory and financial strategy, Interfaces, 14(1), pp. 126-137. doi:10.1287/inte.14.1.126

Sharpe, W.F. (1964) Capital asset prices: a theory of market equilibrium under conditions of risk, Journal of Finance, 19(3), pp. 425-442. doi:10.2307/2977928

Trigeorgis, L. (1999) Real options: managerial flexibility and strategy in resource allocation, Cambridge, M.A.: The MIT Press.

Wey, L. (1993) Effects of mean-reversion on the valuation of offshore oil reserves and optimal investment rules. Unpublished Thesis, Massachusetts Institute of Technology.

Wooldridge, S.C., Garvin, M.J., Cheah, Y.J. and Miller, J.B. (2002) Valuing flexibility in private toll road development: analysis of the Dulles greenway, Journal of Structured Finance, 7(4), pp. 25-36. doi:10.3905/jsf.2002.320264 


\section{SANTRAUKA}

\section{MIŠRIŲ SUSITARIMỤ DE்L SVP PROJEKTŲ FINANSAVIMO İVERTINIMAS: PAGAL MINIMALIAS PAJAMŲ GARANTIJAS IR PAJAMŲ KAPITALIZACIJOS SUSITARIMUS}

\section{Jaebum JUN}

Dèl ribotų viešojo sektoriaus lèšų vyriausybè nusprendè sujungti privačias lèšas pagal SVP (angl. BOT) projektu finansavimo schema. Paprastai SVP projektai yra lanksčiai valdomi, todèl gali sukelti radikaliu pokyčiu grynuosiuose projekto pinigu srautuose asimetrinį atsipirkimą dèl unikalių SVP projektų finansavimo savybiú. Tarp ivvairių lanksčiu SVP projektų valdymo pavyzdžių minètini minimalios pajamų garantijos (angl. MRG) ir pajamų kapitalizacijos (angl. RCP) susitarimai. Jie dažnai naudojami siekiant apsaugoti valdžią ir vystytoją nuo veiklos rizikos. Tačiau bendras minimalių pajamu garantijų ir pajamų kapitalizacijos susitarimu poveikis projekto vertei nesuprantamas ir dèl to, kad tradicinè kapitalo teorija, grynosios dabartinès vertès (angl. NPV) analize yra ribotos vertinant nenumatytus šiu susitarimu atvejus. Taigi šio straipsnio tikslas - plètoti skaitmenini modeli, i̇vertinti bendra minètu susitarimu poveiki projekto vertei, pagrịstai pasirinkto sandorio ịkainojimo teorija, ir pasiūlyti teorini pagrindimą. Šiame straipsnyje taikomas metodas pagristas hipotetiniais SVP rinkliavos atvejais ir kai kuriomis padarytomis išvadomis. Pasirinkto sandorio ¿kainojimo samprata analizuojama atliekant grynosios dabartinès vertės analizę, kol bendra minimaliu pajamų garantijų ir pajamų kapitalizacijos susitarimų vertè tampa labai svarbi, palyginti su projekto verte. 